\section{Gene researchers promised relief from regulatory burden}

[MUNICH] Germany's research minister, Jürgen Rüttgers, has promised to submit proposals to the cabinet suggesting how the conditions for genetic research could be improved, primarily by reducing administrative burdens on researchers and increasing the efficiency of funding.

Rüttgers' promise followed the publication last week of a report by the Research, Technology and Innovation Council, an ad hocadvisory group set up in 1995 to report to Chancellor Helmut Kohl on scientific issues.

After nearly a year's analysis, the council - which includes 26 representatives of the academic community and industry, as well as several politicians - reached familiar conclusions about the problems facing academic and industrial researchers using genetic engineering techniques in Germany.

Despite recent improvements (see Nature $379,670 ; 1996)$, it found that researchers still face delays in gaining approval for experiments, there remain few sources of venture capital, and public hostility to genetic engineering has discouraged research at a time when it has been booming elsewhere.

The report makes 96 recommendations. These include concentrating public funds on a limited number of centres of excellence, and an increase in the number of foreign researchers in these centres. The report suggests more funding for bioinformatics, an area which it warns is dangerously weak in Germany.

The council also says that Germany should rethink what some consider to be an obsessively democratic attitude towards biotechnology, and remove the requirement for a public hearing for major industrial initiatives. Field trials of genetically manipulated crops should be extensively deregulated, it says. These have been a particular target for public hostility (see Nature 380,$94 ; 1996$ ).

The council's report calls for tax breaks for industries conducting research, incentives for venture capitalists to invest in German biotechnology, a single - and cheap - European patent, and more training opportunities in genetic engineering for young scientists.

Detlev Ganten, director of Berlin's Max Delbrück Centre for Molecular Medicine and a member of the advisory council, says that, even if only some of the suggestions are implemented, Germany will have a better chance of catching up with its competitors. Rüttgers has promised to submit his proposals by the autumn.

The report is the second from the council. The first - on the information society was published last year.

A.A.

\title{
Conservatives undermine Italy's university reforms
}

[MUNICH] Hopes for significant reforms to Italy's widely criticized system of academic promotion have been dashed - at least for the near future - by compromises made to satisfy the powerful conservative academic lobby within Italian politics.

Last week, the Italian Senate passed a university bill that fails to solve what many consider to be the central problem with the system - the lack of staff mobility between universities and the powerful influence that personal connections play in making academic appointments.

When Luigi Berlinguer, the minister for education and research and formerly a professor of law at the University of Siena, took office last year, one of his priorities was to change the system by which faculty members are appointed through centrally organized competitions, or concorsi (see Nature 382, 7; 1996).

Winners of these competitions are allocated to individual universities, and deals are often made to ensure that scientists are appointed to institutions with which they have strong connections.

Berlinguer and many others feel that this procedure undermines scientific competitiveness. His original bill proposed that nonItalians should take part in judging committees to reduce the influence of local connections. It said that the number of winners should exceed the places available, giving universities a wider selection of candidates. $\mathrm{He}$ also wanted universities to be barred from appointing a candidate from the same city to the post of professor.
But last week's Senate vote compromises considerably on each of these points. First, it no longer includes a requirement for foreign scientists to sit on judging committees.

Second, candidates would be able to apply for promotion, at any time, to a new threemember national committee, and repeatedly reapply if they do not succeed initially. Successful candidates would remain on a nation-

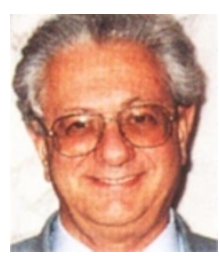
al list for eight years.

Universities would be able to select faculty members from this list, but would not - at least initially - be required to recruit outsiders. A new

Berlinguer: Senate clause introduced into the weakened plans. bill states that those added to the list within its first four years can be recruited locally for a further eight years.

"This means that local candidates, whatever their merit, will become professors, as the local selection committees are likely to choose a local candidate," says Piergiorgio Strata, a professor of neurophysiology at the University of Turin. Strata, an active campaigner for improvements to the Italian academic system, fears that a further generation of academics will be recruited in this way.

The draft law still has to be voted on by the Chamber of Deputies, Italy's lower parliamentary chamber, where it is likely to face a rough ride from conservatives. If it fails to win support, reformers are likely to face a long wait before the issue finds its way back to the top levels of the government's problem-filled agenda.

Alison Abbott

\section{'Britain must tackle lack of trust on funding'}

[LONDON] Britain's Royal Society has asked the winner of this week's general election to tackle the problem of the "increasing lack of trust" between researchers and funding agencies. It wants the new government to establish a "fresh balance" between the freedom of fundamental research teams to choose their own goals and the pressures of accountability in the use of public funds.

The demand is made in a document entitled 'Memorandum for an Incoming Government'. This argues that the perception among scientists of an increasing tendency for research programmes to be defined and directed "from the top down" has led to a situation in which university staff are "beginning to think of research councils as 'the enemy' rather than as agencies designed to help".

The statement makes no direct mention of levels of funding for science. But it does warn whichever party forms the next government of the dangers arising from an increasingly short-term and 'dirigiste' attitude towards fundamental research. Both the ruling Conservative party and its Labour opponents, who were widely expected to win the election, remained discreetly silent about science funding during the election campaign (see Nature 386,314 ; 1997).

The Royal Society asks for an end to "frequent, ideologically motivated reviews" of research establishments. It also offers the services of its 1,200 fellows as a source of scientific advice to the government, hoping that they could be used in a way analogous to the US government's use 'of the madvisory capacity of the National Academy of Sciences. 